\title{
Review Article \\ Effects of Pesticides on the Growth and Reproduction of Earthworm: A Review
}

\author{
Shahla Yasmin ${ }^{1}$ and Doris D'Souza ${ }^{2}$ \\ ${ }^{1}$ Department of Zoology, Patna Women's College, Bailey Road, Patna, 800001 Bihar, India
}

${ }^{2}$ Patna Women's College, Bailey Road, Patna, 800001 Bihar, India

Correspondence should be addressed to Shahla Yasmin, shahla_apex@yahoo.co.in

Received 29 June 2009; Revised 5 January 2010; Accepted 27 January 2010

Academic Editor: Thilagavathy Daniel

Copyright (C) 2010 S. Yasmin and D. D’Souza. This is an open access article distributed under the Creative Commons Attribution License, which permits unrestricted use, distribution, and reproduction in any medium, provided the original work is properly cited.

\begin{abstract}
Scientific literature addressing the influence of pesticides on the growth and reproduction of earthworm is reviewed. Earthworms are considered as important bioindicators of chemical toxicity in the soil ecosystem. Studies on this aspect are important because earthworms are the common prey of many terrestrial vertebrate species such as birds and small mammals, and thus they play a key role in the biomagnification process of several soil pollutants. Majority of the studies have used mortality as an endpoint rather than subtler endpoints such as reproductive output. It is now emphasized that, whereas higher concentrations of a pollutant can easily be assessed with the acute (mortality) test, contaminated soils with lower (sublethal) pollutant concentrations require more sensitive test methods such as reproduction test in their risk assessment.
\end{abstract}

\section{Introduction}

A greater proportion $(>80 \%)$ of biomass of terrestrial invertebrates is represented by earthworms which play an important role in structuring and increasing the nutrient content of the soil. Therefore, they can be suitable bioindicators of chemical contamination of the soil in terrestrial ecosystems providing an early warning of deterioration in soil quality [1-3]. This is important for protecting the health of natural environments and is of increasing interest in the context of protecting human health [4] as well as other terrestrial vertebrates which prey upon earthworms [5]. The suitability of earthworms as bioindicators in soil toxicity is largely due to the fact that they ingest large quantity of the decomposed litter, manure, and other organic matter deposited on soil, helping to convert it into rich topsoil $[6,7]$. Moreover, studies have shown that earthworm skin is a significant route of contaminant uptake [8] and thus investigation of earthworm biomarkers in the ecological risk assessment (ERA) can be helpful [9] .

Eisenia fetida is the standard test organism used in terrestrial ecotoxicology, because it can be easily bred on a variety of organic wastes with short generation times [1013]. Its susceptibility to chemicals resembles that of true soil organisms. Sensitivity tests of multiple earthworm species have revealed that Eisenia fetida is comparatively less sensitive [14-16]. Although, earthworm species vary in their tolerance, reports have shown a decline in earthworm populations in response to large amounts of organic chemical deposition [17].

Mortality has been the most frequently used parameter to evaluate the chemical toxicity in earthworms [18-20]. It is postulated, however, that survival is less sensitive from an ecotoxicological point of view [21] and acute mortality tests would not provide the most sensitive risk estimate for earthworms in the majority (95\%) of cases [22]. Amorim et al. [23] tested with herbicide Phenmedipham and found reproduction to be a more sensitive endpoint than mortality in Enchytraeus albidus and Enchytraeus luxuriosus. It is suggested that the chronic test, aiming at sublethal effects, is more sensitive and is a more realistic approach for the prediction of environmental effects because in the field, the exposure concentrations of pesticides are usually quite low [24]. Moreover, the lethal effect of a chemical is not a necessary consequence in intoxication and sublethal effects 
may be produced. According to Riepert et al. [25] the acute earthworm test is part of the basic test set, but the earthworm reproduction test is considered ecologically more relevant. Therefore, growth and reproduction have been recommended as useful sub lethal criteria [26, 27]. This article reviews in short the available scientific literature on the effects of pesticides on the key biological processes, that is growth and reproduction of earthworms.

\section{Sublethal Toxicity Testing Method}

The earthworm reproduction test with Eisenia fetida/Eisenia andrei aims to assess the impact of soil contaminants on sublethal parameters in earthworms. Endpoints include reproductive parameters (cocoon production per adult per week, juveniles hatching per adult per week and cocoon viability) and weight change of adults. During the test, adult mature worms are exposed to different concentrations of a substance (pollutant) in a standard test soil; when field soils are used, homogenised and air-dried soil samples are sieved and added to the test chamber and brought to a given moisture content. Ten acclimatized individuals are added to each vessel containing $500 \mathrm{~g}$ dry weight of the selected soil. Growth effects and mortality are determined after four weeks and effects on reproduction are assessed after eight weeks of exposure. The assay has been used to measure the effects of a wide range of chemicals such as metals [28] and pesticides [29]. In addition use of a suitable control soil is essential. This test is standardized at the international level, being recognized and promoted by international organizations (OECD_Organization of Economical Cooperation and Development, and ISOInternational Organization of Standardization), aiming to elaborate international guidelines on environment quality assessment.

\section{Effects on Growth}

A number of studies have been conducted on the standard worm Eisenia fetida/andrei. Some of the responses of earthworms to sublethal concentrations of pesticides is shown in Table 1. Zhou et al. [30] have reported that the weight of the earthworms was a more sensitive index compared to the mortality in indicating toxic effects of acetochlor and methamidophos. Espinoza-Navarro and BustosObregón [31] treated Eisenia fetida with organophosphate insecticide malathion and Bustos-Obregón and Goicochea [3] explored the effect of exposure to commercial parathion on Eisenia fetida; both observed decrease in the body weight of treated worms. Weight loss has also been reported for organochlorine pesticides intoxication $[18,32,33]$ and for the effects of fungicides and herbicides in Eisenia fetida and Lumbricus terrestris [34-36]. Choo and Baker [37] found endosulfan did significantly reduce the weight of juvenile Aporrectodea trapezoides within 5 weeks when applied to soil at normal application rate in both the field and laboratory while fenamiphos did so at normal application rate in the field only. Both fenamiphos and methiocarb reduced earthworm weight in the laboratory when applied at $10 \times$ normal rate. Weight loss appears to be a valuable indicator of physiological stress, related to the degree of intoxication and time of exposure [22, 38]. Coiling, another symptom seen in $100 \%$ of the Parathion treated worms, is related with weight loss and is regarded as the consequence of alteration in muscular function elicited by organophosphoric pesticides which may explain the difficulties for locomotion of the intoxicated worms and their relative inability to feed themselves [3].

Negative impact of pesticides on earthworm growth has been reported by various researchers. Xiao et al. [39] suggested that growth can be regarded as sensitive parameters to evaluate the toxicity of acetochlor on earthworms. Helling et al. [36] tested in laboratory the effect of copper oxychloride, while Yasmin and D'Souza [40] investigated the impact of carbendazim, glyphosate and dimethoate on Eisenia fetida and found a significant reduction in the earthworm growth in a dose-dependent manner. According to Van Gestel et al. [27] parathion affects the growth of Eisenia andrei. Booth et al. [41] studied the effect of two organophosphates, chlorpyrifos and diazinon, while Mosleh et al. [42] investigated the toxicity of aldicarb, cypermethrin, profenofos, chlorfluazuron, atrazine, and metalaxyl in the earthworm Aporrectodea caliginosa and observed a reduction in growth rate in all pesticide-treated worms. Mosleh et al. [43, 44] studied the effects of endosulfan and aldicarb on Lumbricus terrestris and have suggested growth rate as important biomarkers for contamination by endosulfan and aldicarb. Zhou et al. [45] assessed and found chlorpyrifos had adverse effect on growth in earthworm exposed to $5 \mathrm{mg} / \mathrm{kg}$ chlorpyrifos after eight weeks. Some studies have shown that growth of earthworms appeared to be more severely affected at juvenile stage than at adult stage $[46,47]$.

\section{Effects on Reproduction}

Numerous reproductive parameters have been studied in earthworms exposed to various xenobiotics: cocoon and hatchling production, viability of the worms produced [ 18 , 20, 48-54], and sexual maturation [50]. Cocoon production was found to be the most sensitive parameter for paraquat, fentin, benomyl, phenmedipham, carbaryl, copper oxychloride, dieldrin $[36,55-57]$, while cocoon hatchability was most sensitive for pentachlorophenol, parathion and carbendazim, copper oxychloride $[36,55,56]$. Bustos-Obregón and Goicochea [3] explored the effect of exposure to commercial parathion on the reproductive parameters such as sperm and cocoon production and genotoxicity on male germ cells of Eisenia fetida and reported that alterations in reproductive parameters were conspicuous in regard to the number of sperm, cocoons, and worms born. Numbers of juveniles per cocoon can be regarded as sensitive parameters to evaluate the toxicity of acetochlor on earthworms as reported by Xiao et al. [39]. Choo and Baker [37] also found that cocoon production in Aporrectodea trapezoides was inhibited by endosulfan and fenamiphos at normal application rates and methiocarb at $10 \times$ normal rate. 


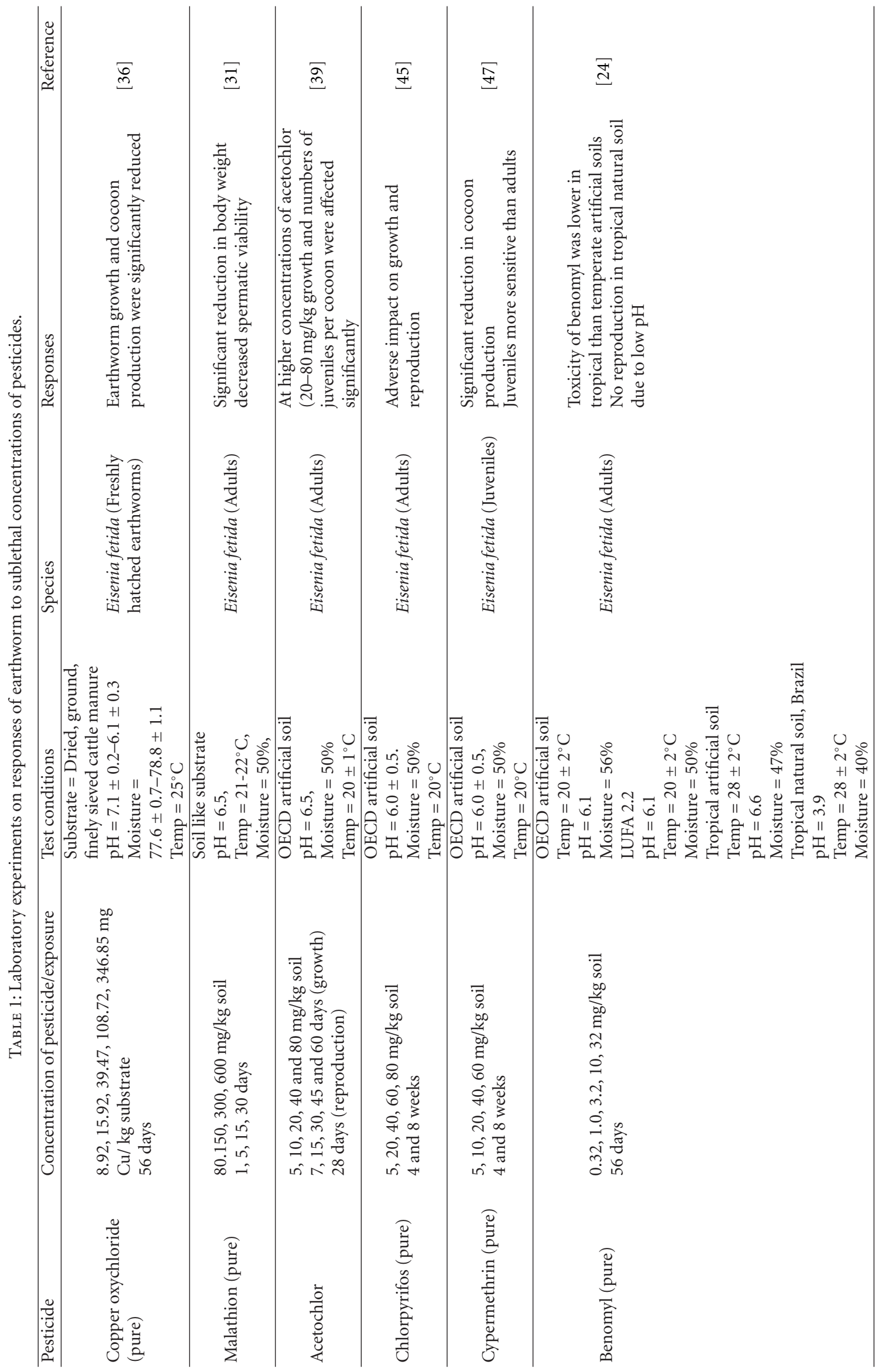




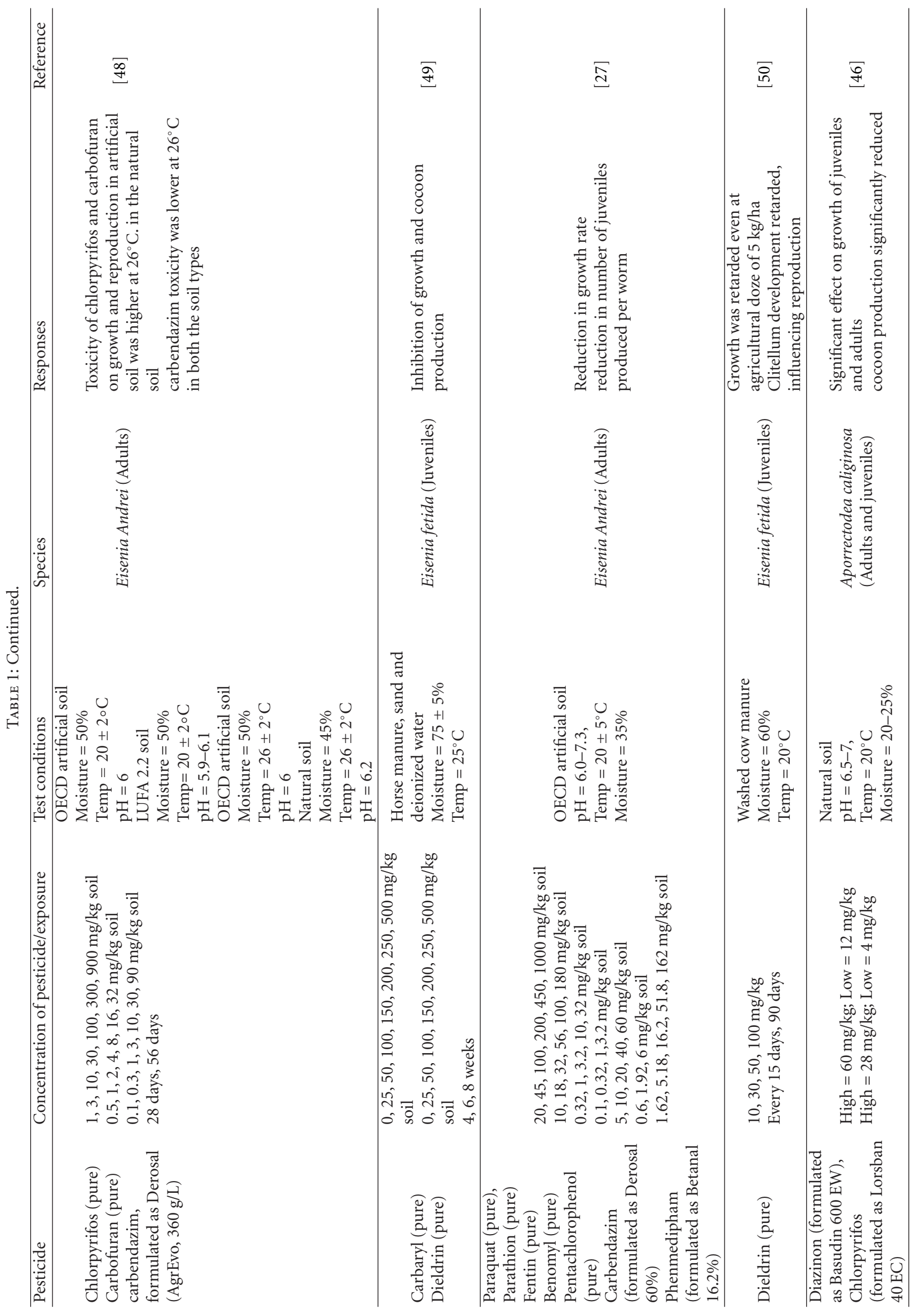




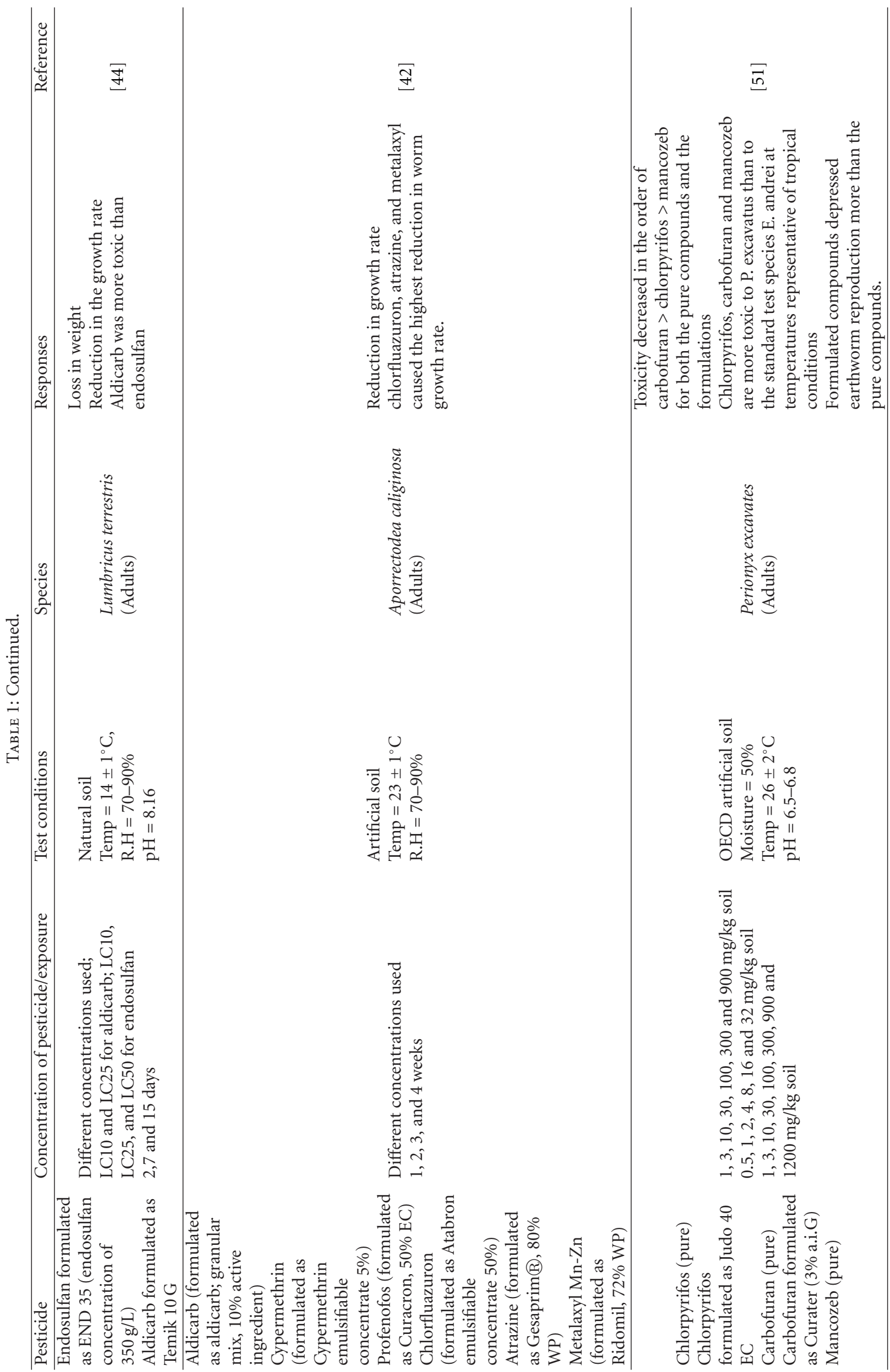


Espinoza-Navarro and Bustos-Obregón [31] treated Eisenia fetida with organophosphate insecticide malathion and found that malathion decreased the spermatic viability in spermatheca, altering the cell proliferation and modifying the DNA structure of spermatogonia. Sperm count also seems to be a very sensitive marker $[42,50]$, malathion could affect the sperm count, but in addition, its metabolites could affect sperm quality [58].

Several scientists have reported that pesticides influence the reproduction (cocoon production, a reduced mean and maximum number of hatchlings per cocoon, and a longer incubation time) of worms in a dose-dependent manner, with greater impact at higher concentration of chemical [35, 40, 41, 56]. Gupta and Saxena [56] studied the effects of carbaryl, an $\mathrm{N}$-methyl carbamate insecticide, on the reproductive profiles of the earthworm, Metaphire posthuma and found sperm head abnormalities even at the lowest test concentration of $0.125 \mathrm{mg} / \mathrm{kg}$. Wavy head abnormalities were observed at $0.125 \mathrm{mg} / \mathrm{kg}$ carbaryl, whereas at $0.25 \mathrm{mg} / \mathrm{kg}$ and $0.5 \mathrm{mg} / \mathrm{kg}$, the sperm heads became amorphous and the head nucleus was turned into granules deposited within the wavy head.

Xiao et al. [39] showed that acetochlor had no longterm effect on the reproduction of Eisenia fetida at field dose $\left(5-10 \mathrm{mg} / \mathrm{kg}^{-1}\right)$. At higher concentrations, acetochlor $(20-80 \mathrm{mg} / \mathrm{kg})$ revealed sublethal toxicity to Eisenia fetida. Zhou et al. [45] assessed and found chlorpyrifos had adverse effect on fecundity in earthworm exposed to $5 \mathrm{mg} / \mathrm{kg}$ chlorpyrifos after eight weeks. According to Zhou et al. [47] reproduction of earthworms appeared to be more severely affected by cypermethrin at juvenile stage than at adult stage. Application of $20 \mathrm{mg} / \mathrm{kg}$, cypermethrin caused significant toxic effects in reproduction of worms.

Coiling, seen in the parathion treated worms, interferes with the reproduction too since worms find their partner less easily and copulation is abnormal in terms of mating posture. Ejection of sperm seems also to be hindered and therefore a large number of spermatozoa are found in intoxicated worms in spite of a clear effect on sperm production under parathion treatment as discussed by Bustos-Obregón and Goicochea [3]. According to Espinoza-Navarro and BustosObregon [58] malathion also has a direct cytotoxic effect causing coiling of the tail, with increase of metachromasia of the chromatin of the spermatozoa and altering the sperm count

\section{Confounding Variables}

The results of earthworm ecotoxicological tests may be confounded with different properties of soils such as organic matter, water holding capacity, $\mathrm{pH}$, cation exchange capacity, Carbon/Nitrogen ratio, and clay content and its interaction with chemical substances and different species of earthworm chosen as test species [23]. Soil pH may affect the survival of adults and thus production of juveniles [23, 59]. Low reproduction of earthworm was seen in finely sieved soil as compared to sandy soil [23] indicating that porosity of soil may influence earthworm mobility and gaseous exchange, thus affecting its life cycle. Further, the effects of a pesticide can differ strongly when tested under tropical and temperate conditions [24]. This may be because the physicochemical variables affecting the biotic processes as well as the fate of pesticides in the tropics are different from those in temperate regions $[60,61]$. The high temperature and humidity, found in the tropics, seem to favor degradation and volatilization of the chemical in the soil $[62,63]$. On the other hand, humid and warmer conditions might enhance the toxicity of some pesticides by increasing the penetration through the skin of animals, and these might be taken up more quickly by tropical biota [64].

Furthermore, information on the side effects of pesticides in the tropics is scarce [65] and a risk assessment based on temperate data could be less appropriate for tropical conditions. Some of the studies have been conducted in this direction, for example, Garcia [66] attempted to compare the toxicity of selected pesticides on different strains of Eisenia fetida in temperate and tropical conditions, whereas, Helling et al. [36], Römbke et al. [24], and Garcia et al. [67] applied standardized protocols to determine pesticide effects to soil invertebrates under tropical conditions. De Silva et al. [48] found that sublethal effects (reproduction and growth) varied inconsistently with temperature and soil types. All these researchers suggested that toxicity of pesticides in tropics cannot be predicted from data generated under temperate conditions, even within the same species [48]. Furthermore, it is suggested that tropical risk assessment may be more realistic when conducted on ecologically relevant earthworm species, rather than standard Eisenia sp [51]. De Silva [68] suggests that Eisenia being temperate compost worms is less ecologically relevant and Perionyx excavatus may be used as standard test species for tropical soils.

An important aim in earthworm ecotoxicology is to be able to predict the effects of harmful chemicals in the field on the basis of laboratory experiments. Holmstrup [69] estimated the in situ cocoon production in grassland of two earthworm species, Aporrectodea longa and Aporrectodea rosea, in relation to application dose of benomyl. The results obtained in this field study were compared with results from laboratory reproduction tests with other earthworm species. There was good agreement between effects of benomyl on reproduction in the laboratory and in the field. These results therefore suggest that standardized laboratory tests provide a reasonable prediction of the effect in the field. However, according to Van Gestel [55], results of field studies on the earthworm toxicity of pesticides are in agreement with those of laboratory studies when a homogeneous distribution of the pesticide dosage over the top $2.5-\mathrm{cm}$ soil layer is chosen as a starting point. In field situations, earthworm exposure is strongly dependent on the degree of deposition of pesticides on the soil surface, on the behavior of the pesticide in the soil, and on the vertical distribution of earthworms in the soil. The soil ecosystem is very complex, where interaction occurs between abiotic and biotic factors. Therefore, extrapolation of effects of pesticides observed in laboratory studies to effects in the field studies may be impeded by various environmental variables (especially the soil characteristics and weather conditions) influencing 
exposure of earthworms to chemical [15]. Neuhauser and Callahan [49] suggested that more consideration should be given to evaluation of sublethal effects under field conditions. Ecotoxicological studies on soil fauna in laboratories usually involve single or a few species. For proper environmental risk assessment, three tiered studies should be conducted [70], that is (1) basic laboratory tests (mainly acute); (2) extended laboratory tests (mainly chronic); (3) tests using microcosms (model ecosystem tests) or even field tests. Although, the highest tier is most important for an ecotoxicological risk assessment, it is rarely performed due to its high complexity, costs and time needed [71]. De Silva [68] also indicates that linking of laboratory data to field may be possible and successful, but more research is required (especially w.r.t tropical conditions) on this aspect to state conclusively [15, $55,69,72,73]$.

In conclusion, growth and reproductive parameters of earthworms exposed to agropesticides seem to be useful bioindicators of soil pollution. Such studies are simple to do and do not require great technical expertise. However, the studies conducted so far have focused on a few species of earthworms. Additional studies with different species of earthworm, including different endpoints, temperature regimes and soil types, are required. Research should be extended to ecologically relevant species of earthworms, as stated earlier [51], and also to other soil fauna to get a comprehensive knowledge on the malfunction in the soil biological processes due to pesticide pollution. All of the above-mentioned studies indicate negative impact of pesticides on earthworm growth and reproduction. Some studies also indicate that microorganisms in the soil help degrade the chemicals $[74,75]$. So, there is a need to acquire more knowledge on the chemical nature, mode of action, and means of degradation of pesticides in soil, so that harm caused to soil fauna as well as to organisms higher up in the food chain can be minimized.

\section{Acknowledgments}

We are grateful to P.M.C.S. De Silva and J. Rombke for providing full texts of several references that helped us immensely in preparing this manuscript.

\section{References}

[1] M. D. Culy and E. C. Berry, "Toxicity of soil-applied granular insecticides to earthworm populations in cornfields," Down to Earth, vol. 50, pp. 20-25, 1995.

[2] J. Sorour and O. Larink, "Toxic effects of benomyl on the ultrastructure during spermatogenesis of the earthworm Eisenia fetida," Ecotoxicology and Environmental Safety, vol. 50, no. 3, pp. 180-188, 2001.

[3] E. Bustos-Obregón and R. I. Goicochea, "Pesticide soil contamination mainly affects earthworm male reproductive parameters," Asian Journal of Andrology, vol. 4, no. 3, pp. 195199, 2002.

[4] A. Beeby, "What do sentinels stand for?" Environmental Pollution, vol. 112, no. 2, pp. 285-298, 2001.

[5] G. Dell'Omo, A. Turk, and R. F. Shore, "Secondary poisoning in the common shrew (Sorex araneus) fed earthworms exposed to an organophosphate pesticide," Environmental Toxicology and Chemistry, vol. 18, no. 2, pp. 237-240, 1999.

[6] S. A. Reinecke and A. J. Reinecke, "Lysosomal response of earthworm coelomocytes induced by longterm experimental exposure to heavy metals," Pedobiologia, vol. 43, no. 6, pp. 585593, 1999.

[7] M. C. Sandoval, M. Veiga, J. Hinton, and B. Klein, "Review of biological indicators for metal mining effluents: a proposed protocol using earthworms," in Proceedings of the 25th Annual British Columbia Reclamation Symposium, pp. 67-79, 2001.

[8] K. A. Lord, G. G. Briggs, M. C. Neale, and R. Manlove, "Uptake of pesticides from water and soil by earthworms," Pesticide Science, vol. 11, no. 4, pp. 401-408, 1980.

[9] J. C. Sanchez-Hernandez, "Earthworm biomarkers in ecological risk assessment," Reviews of Environmental Contamination and Toxicology, vol. 188, pp. 85-126, 2006.

[10] ISO, "Soil quality_effects of pollutants on earthworms (Eisenia fetida)—part 1: determination of acute toxicity using artificial soil substrate," ISO 11268-1, International Organization for Standardization, Geneva, Switzerland, 1993.

[11] ISO, "Soil quality - effects of pollutants on earthworms (Eisenia fetida) - part 2: determination of effects on reproduction," ISO 11268-2, International Organization for Standardization, Geneva, Switzerland, 1998.

[12] OECD, "Guideline for testing of chemicals," no. 207, Earthworm Acute Toxicity Test. Organization for Economic CoOperation and Development, Paris, France, 1984.

[13] OECD, "Guideline for testing of chemicals," no. 222, Earthworm Reproduction Test (Eisenia fetida/andrei). Organization for Economic Co-Operation and Development, Paris, France, 2004.

[14] W. C. Ma and J. Bodt, "Differences in toxicity of the insecticide chlorpyrifos to six species of earthworms (Oligochaeta, Lumbricidae) in standardized soil tests," Bulletin of Environmental Contamination and Toxicology, vol. 50, no. 6, pp. 864-870, 1993.

[15] H. Kula, "Comparison of laboratory and field testing for the assessment of pesticide side effects on earthworms," Acta Zoologica Fennica, vol. 196, pp. 338-341, 1995.

[16] D. G. Fitzgerald, K. A. Warner, R. P. Lanno, and D. G. Dixon, "Assessing the effects of modifying factors on pentachlorophenol toxicity to earthworms: applications of body residues," Environmental Toxicology and Chemistry, vol. 15, no. 12, pp. 2299-2304, 1996.

[17] D. E. Bayer and C. L. Foy, "Action and fate of adjuvants in soils," in Adjuvants for Herbicides, pp. 84-92, WSSA, Champaign, Ill, USA, 1982.

[18] C. A. M. Van Gestel and W. A. Van Dis, "The influence of soil characteristics on the toxicity of four chemicals to the earthworm Eisenia fetida andrei (Oligochaeta)," Biology and Fertility of Soils, vol. 6, no. 3, pp. 262-265, 1988.

[19] C. A. M. Van Gestel, W. A. Van Dis, E. M. Van Breemen, and P. M. Sparenburg, "Development of a standardized reproduction toxicity test with the earthworm species Eisenia fetida andrei using copper, pentachlorophenol, and 2,4-dichloroaniline," Ecotoxicology and Environmental Safety, vol. 18, no. 3, pp. 305312, 1989.

[20] P. Y. Robidoux, J. Hawari, S. Thiboutot, G. Ampleman, and G. I. Sunahara, "Acute toxicity of 2,4,6-trinitrotoluene in earthworm (Eisenia andrei)," Ecotoxicology and Environmental Safety, vol. 44, no. 3, pp. 311-321, 1999. 
[21] F. Moriarty, Ecotoxicology: The Study of Pollutants in Ecosystems, Academic Press, London, UK, 1983.

[22] G. K. Frampton, S. Jänsch, J. J. Scott-Fordsmand, J. Römbke, and P. J. Van den Brink, "Effects of pesticides on soil invertebrates in laboratory studies: a review and analysis using species sensitivity distributions," Environmental Toxicology and Chemistry, vol. 25, no. 9, pp. 2480-2489, 2006.

[23] M. J. B. Amorim, J. Römbke, and A. M. V. M. Soares, "Avoidance behaviour of Enchytraeus albidus: effects of Benomyl, Carbendazim, phenmedipham and different soil types," Chemosphere, vol. 59, no. 4, pp. 501-510, 2005.

[24] J. Römbke, M. V. Garcia, and A. Scheffczyk, "Effects of the fungicide benomyl on earthworms in laboratory tests under tropical and temperate conditions," Archives of Environmental Contamination and Toxicology, vol. 53, no. 4, pp. 590-598, 2007.

[25] F. Riepert, J. Römbke, and T. Moser, Ecotoxicological Characterization of Waste, Springer, New York, NY, USA, 2009.

[26] M.G. Paoletti, "The role of earthworms for assessment of sustainability and as bioindicators," Agriculture, Ecosystems and Environment, vol. 74, no. 1-3, pp. 137-155, 1999.

[27] C. A. M. Van Gestel, E. M. Dirven-Van Breemen, R. Baerselman, et al., "Comparison of sublethal and lethal criteria for nine different chemicals in standardized toxicity tests using the earthworm Eisenia andrei," Ecotoxicology and Environmental Safety, vol. 23, no. 2, pp. 206-220, 1992.

[28] K. Lock and C. R. Janssen, "Cadmium toxicity for terrestrial invertebrates: taking soil parameters affecting bioavailability into account," Ecotoxicology, vol. 10, no. 5, pp. 315-322, 2001.

[29] H. Kula and O. Larink, "Development and standardization of test methods for the prediction of sublethal effects of chemicals on earthworms," Soil Biology and Biochemistry, vol. 29, no. 3-4, pp. 635-639, 1997.

[30] Q.-X. Zhou, Q.-R. Zhang, and J.-D. Liang, "Toxic effects of acetochlor and methamidophos on earthworm Eisenia fetida in phaiozem, northeast China," Journal of Environmental Sciences, vol. 18, no. 4, pp. 741-745, 2006.

[31] O. Espinoza-Navarro and E. Bustos-Obregón, "Effect of malathion on the male reproductive organs of earthworms, Eisenia foetida," Asian Journal of Andrology, vol. 7, no. 1, pp. 97-101, 2005.

[32] M. Cikutovic, Pathologies in earthworm: sub lethal biomarkers of xenobiotic toxicity, dissertation, University of North Texas, 1991.

[33] E. Martikainen, "Toxicity of dimethoate to some soil animal species in different soil types," Ecotoxicology and Environmental Safety, vol. 33, no. 2, pp. 128-136, 1996.

[34] A. Haque and W. Ebing, "Toxicity determination of pesticides to earthworms in the soil substrate," Journal of Plant Diseases and Protection, vol. 90, no. 4, pp. 395-408, 1983.

[35] J. A. Addison and S. B. Holmes, "Comparison of forest soil microcosm and acute toxicity studies for determining effects of fenitrothion on earthworms," Ecotoxicology and Environmental Safety, vol. 30, no. 2, pp. 127-133, 1995.

[36] B. Helling, S. A. Reinecke, and A. J. Reinecke, "Effects of the fungicide copper oxychloride on the growth and reproduction of Eisenia fetida (Oligochaeta)," Ecotoxicology and Environmental Safety, vol. 46, no. 1, pp. 108-116, 2000.

[37] L. P. D. Choo and G. H. Baker, "Influence of four commonly used pesticides on the survival, growth, and reproduction of the earthworm Aporrectodea trapezoides (Lumbricidae)," Australian Journal of Agricultural Research, vol. 49, no. 8, pp. 1297-1303, 1998.
[38] C. A. M. Van Gestel, J. Zaal, E. M. Dirven-Van Breemen, and R. Baerselman, "Comparison of two test methods for determining the effects of pesticides on earthworm reproduction," Acta Zoologica Fennica, vol. 196, pp. 278-283, 1995.

[39] N. Xiao, B. Jing, F. Ge, and X. Liu, "The fate of herbicide acetochlor and its toxicity to Eisenia fetida under laboratory conditions," Chemosphere, vol. 62, no. 8, pp. 1366-1373, 2006.

[40] S. Yasmin and D. D'Souza, "Effect of pesticides on the reproductive output of Eisenia fetida," Bulletin of Environmental Contamination and Toxicology, vol. 79, no. 5, pp. 529-532, 2007.

[41] L. H. Booth, V. J. Heppelthwaite, and K. O’Halloran, “Growth, development and fecundity of the earthworm Aporrectodea caliginosa after exposure to two organophosphates," New Zealand Plant Protection, vol. 53, pp. 221-225, 2000.

[42] Y. Y. Mosleh, S. M. M. Ismail, M. T. Ahmed, and Y. M. Ahmed, "Comparative toxicity and biochemical responses of certain pesticides to the mature earthworm Aporrectodea caliginosa under laboratory conditions," Environmental Toxicology, vol. 18, no. 5, pp. 338-346, 2003.

[43] Y. Y. Mosleh, S. Paris-Palacios, M. Couderchet, and G. Vernet, "Biological effects of two insecticides on earthworms (Lumbricus terrestris L.) under laboratory conditions," Mededelingen Rijksuniversiteit te Gent. Fakulteit van de Landbouwkundige en Toegepaste Biologische Wetenschappen, vol. 67, no. 2, pp. 59-68, 2002.

[44] Y. Y. Mosleh, S. Paris-Palacios, M. Couderchet, and G. Vernet, "Acute and sublethal effects of two insecticides on earthworms (Lumbricus terrestris L.) under laboratory conditions," Environmental Toxicology, vol. 18, no. 1, pp. 1-8, 2003.

[45] S.-P. Zhou, C.-Q. Duan, H. Fu, Y.-H. Chen, X.-H. Wang, and Z.-F. Yu, "Toxicity assessment for chlorpyrifos-contaminated soil with three different earthworm test methods," Journal of Environmental Sciences, vol. 19, no. 7, pp. 854-858, 2007.

[46] L. H. Booth and K. O'Halloran, “A comparison of biomarker responses in the earthworm Aporrectodea caliginosa to the organophosphorus insecticides diazinon and chlorpyrifos," Environmental Toxicology and Chemistry, vol. 20, no. 11, pp. 2494-2502, 2001.

[47] S. Zhou, C. Duan, X. Wang, W. H. G. Michelle, Z. Yu, and $\mathrm{H}$. Fu, "Assessing cypermethrin-contaminated soil with three different earthworm test methods," Journal of Environmental Sciences, vol. 20, no. 11, pp. 1381-1385, 2008.

[48] P. M. C. S. De Silva, A. Pathiratne, and C. A. M. van Gestel, "Influence of temperature and soil type on the toxicity of three pesticides to Eisenia andrei," Chemosphere, vol. 76, no. 10, pp. 1410-1415, 2009.

[49] E. F. Neuhauser and C. A. Callahan, "Growth and reproduction of the earthworm Eisenia fetida exposed to sublethal concentrations of organic chemicals," Soil Biology and Biochemistry, vol. 22, no. 2, pp. 175-179, 1990.

[50] J. M. Venter and A. J. Reinecke, "Dieldrin and growth and development of the earthworm, Eisenia fetida (oligochaeta)," Bulletin of Environmental Contamination and Toxicology, vol. 35, no. 5, pp. 652-659, 1985.

[51] P. M. C. S. De Silva, A. Pathiratne, and C. A. M. van Gestel, "Toxicity of chlorpyrifos, carbofuran, mancozeb and their formulations to the tropical earthworm Perionyx excavatus," Applied Soil Ecology, vol. 44, no. 1, pp. 56-60, 2010.

[52] P. Y. Robidoux, C. Svendsen, J. Caumartin, et al., "Chronic toxicity of energetic compounds in soil determined using the earthworm (Eisenia andrei) reproduction test," Environmental Toxicology and Chemistry, vol. 19, no. 7, pp. 1764-1773, 2000. 
[53] S. A. Reinecke, M. W. Prinsloo, and A. J. Reinecke, "Resistance of Eisenia fetida (Oligochaeta) to cadmium after long-term exposure," Ecotoxicology and Environmental Safety, vol. 42, no. 1, pp. 75-80, 1999.

[54] M. S. Maboeta, A. J. Reinecke, and S. A. Reinecke, "Effects of low levels of lead on growth and reproduction of the Asian earthworm Perionyx excavatus (Oligochaeta)," Ecotoxicology and Environmental Safety, vol. 44, no. 3, pp. 236-240, 1999.

[55] C. A. M. Van Gestel, "Validation of earthworm toxicity tests by comparison with field studies: a review of benomyl, carbendazim, carbofuran, and carbaryl," Ecotoxicology and Environmental Safety, vol. 23, no. 2, pp. 221-236, 1992.

[56] S. K. Gupta and P. N. Saxena, "Carbaryl-induced behavioural and reproductive abnormalities in the earthworm Metaphire posthuma: a sensitive model," Alternatives to Laboratory Animals, vol. 31, no. 6, pp. 587-593, 2003.

[57] M. A. Cikutovic, L. C. Fitzpatrick, B. J. Venables, and A. J. Goven, "Sperm count in earthworms (Lumbricus terrestris) as a biomarker for environmental toxicology: effects of cadmium and chlordane," Environmental Pollution, vol. 81, no. 2, pp. 123-125, 1993.

[58] O. Espinoza-Navarro and E. Bustos-Obregón, "Sublethal doses of malathion alter male reproductive parameters of Eisenia fetida," International Journal of Morphology, vol. 22, no. 4, pp. 297-302, 2004.

[59] M. J. Amorim, J. P. Sousa, A. J. A. Nogueira, and A. M. V. M. Soares, "Comparison of chronic toxicity of Lindane $(\gamma-\mathrm{HCH})$ to Enchytraeus albidus in two soil types: the influence of soil pH," Pedobiologia, vol. 43, no. 6, pp. 635-640, 1999.

[60] V. Laabs, W. Amelung, A. Pinto, and W. Zech, "Fate of pesticides in tropical soils of Brazil under field conditions," Journal of Environmental Quality, vol. 31, no. 1, pp. 256-268, 2002.

[61] L. C. Paraíba, A. L. Cerdeira, E. F. Da Silva, J. S. Martins, and H. L. Da Costa Coutinho, "Evaluation of soil temperature effect on herbicide leaching potential into groundwater in the Brazilian Cerrado," Chemosphere, vol. 53, no. 9, pp. 10871095, 2003.

[62] W. Klein, "Mobility of environmental chemicals, including abiotic degradation," in Ecotoxicology and Climate. SCOPE 38, P. Bordeau, J. A. Haines, W. Klein, and C. R. Krishna Murti, Eds., pp. 65-78, John Wiley \& Sons, Chichester, UK, 1989.

[63] P. Bourdeau, J. A. Haines, W. Klein, and C. R. Krishnamurti, "Ecotoxicology and climate," in SCOPE 38 IPCS Joint Symposia 9, p. 392, John Wiley \& Sons, Chichester, UK, 1989.

[64] P. N. Viswanathan and C. R. Krishnamurti, "Effects of temperature and humidity on ecotoxicology of chemicals," in Ecotoxicology and Climate with Special Reference to Hot and Cold Climates, P. Bourdeau, J. A. Haines, W. Klein, and C. R. Krishanamurti, Eds., pp. 139-154, John Wiley \& Sons, New York, NY, USA, 1989.

[65] P. J. Van den Brink, S. N. Sureshkumar, M. A. Daam, et al., "Environmental and human risk of pesticide use in Thailand and Sri Lanka. Results of a preliminary risk assessment," Alterra Report 789. MAMAS Report Series No. 3/2003, Research Institute for the Green World, Wageningen Alterra, The Netherlands, 2003.

[66] M. V. B. Garcia, Effects of Pesticides on Soil Fauna: Development of Ecotoxicological Test Methods for Tropical Regions, vol. 19 of Ecology and Development Series, University of Bonn, Bonn, Germany, 2004.

[67] M. Garcia, J. Römbke, M. T. de Brito, and A. Scheffczyk, "Effects of three pesticides on the avoidance behavior of earthworms in laboratory tests performed under temperate and tropical conditions," Environmental Pollution, vol. 153, no. 2, pp. 450-456, 2008.

[68] P. M. C. S. De Silva, Pesticide effects on earthworms: a tropical perspective, Ph.D. thesis, Department of Ecological Science, VU University, Amsterdam, The Netherlands, 2009.

[69] M. Holmstrup, "Field assessment of toxic effects on reproduction in the earthworms Aporrectodea longa and Aporrectodea rosea," Environmental Toxicology and Chemistry, vol. 19, no. 7, pp. 1781-1787, 2000.

[70] J. Römbke, C. Bauer, and A. Marschner, "Hazard assessment of chemicals in soil-proposed ecotoxicological test strategy," Environmental Science and Pollution Research, vol. 3, no. 2, pp. 78-82, 1996.

[71] J. Römbke and J. Notenboom, "Ecotoxicological approaches in the field," in Environmental Analysis of Contaminated Sites, G. I. Sunahara, A. Y. Renoux, C. Thellen, C. L. Gaudet, and A. Pilon, Eds., pp. 181-195, John Wiley \& Sons, Chichester, UK, 2002.

[72] F. Heimbach, "Correlation between data from laboratory and field tests for investigating the toxicity of pesticides to earthworms," Soil Biology and Biochemistry, vol. 24, no. 12, pp. 1749-1753, 1992.

[73] S. Jänsch, G. K. Frampton, J. Römbke, P. J. Van den Brink, and J. J. Scott-Fordsmand, "Effects of pesticides on soil invertebrates in model ecosystem and field studies: a review and comparison with laboratory toxicity data," Environmental Toxicology and Chemistry, vol. 25, no. 9, pp. 2490-2501, 2006.

[74] A. R. Abdullah, C. M. Bajet, M. A. Matin, D. D. Nhan, and A. H. Sulaiman, "Ecotoxicology of pesticides in the tropical paddy field ecosystem," Environmental Toxicology and Chemistry, vol. 16, no. 1, pp. 59-70, 1997.

[75] B. K. Singh, A. Walker, J. A. W. Morgan, and D. J. Wright, "Effects of soil $\mathrm{pH}$ on the biodegradation of chlorpyrifos and isolation of a chlorpyrifos-degrading bacterium," Applied and Environmental Microbiology, vol. 69, no. 9, pp. 5198-5206, 2003. 




Submit your manuscripts at

http://www.hindawi.com
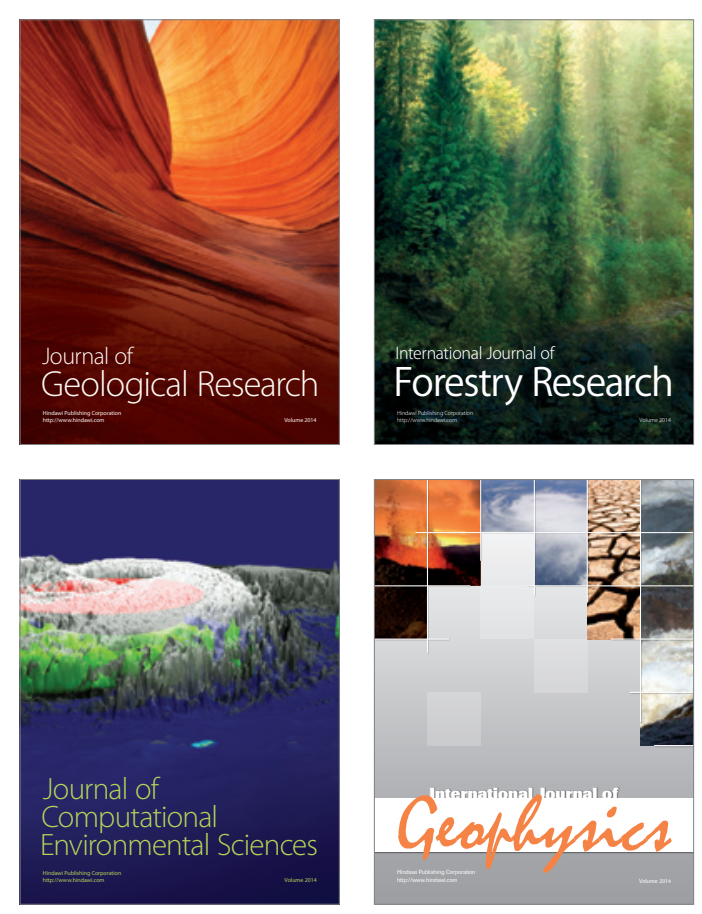
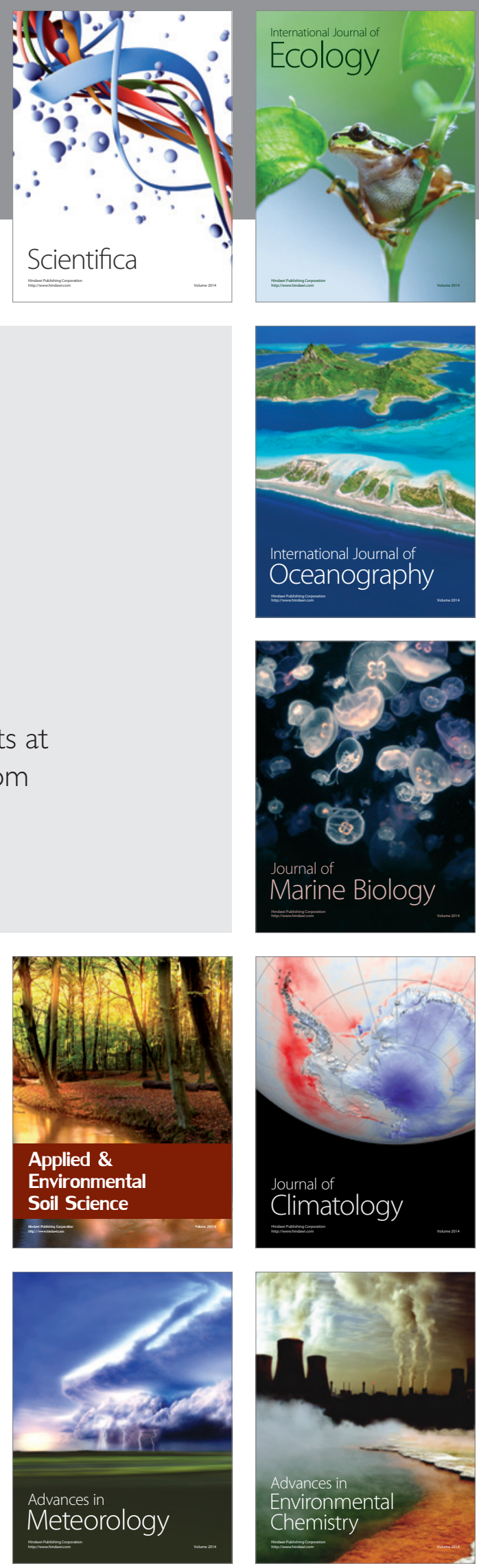